\section{EREM 76/3}

Journal of Environmental Research Engineering and Management Vol. 76 / No.3 / 2020 pp. 84-95 DOI 10.5755/j01.erem.76.3.25365
The Typicality of Hydrothermal Conditions of the Forest Steppe and Their Influence on the Productivity of Crops

Received 2020/02 Accepted after revision 2020/08

\title{
The Typicality of Hydrothermal Conditions of the Forest Steppe and Their Influence on the Productivity of Crops
}

\section{Dmytro Litvinov, Olena Litvinova}

National University of Life and Environmental Sciences of Ukraine, 12 Heroyiv Oborony St., Kyiv, 03041, Ukraine

\section{Natalia Borys}

National Science Center, Institute of Agriculture NAAS Ukraine, 2b Mashynobudivnykiv St., Chabany, 08162, Ukraine

\section{Andrii Butenko*, Ihor Masyk, Viktor Onychko, Lidiia Khomenko, Nataliia Terokhina, Serhii Kharchenko \\ Sumy National Agrarian University, 160 Herasym Kondratiev St., Sumy, 40021, Ukraine}

*Corresponding author: andb201727@ukr.net

Analysis of changes in hydrothermal conditions of growing crops in the forest steppe zone of Ukraine over a period of 2004-2016 showed that by the average monthly air temperature more than a half of the years under study and by rainfall nearly a third of the researched period differed significantly from the average long-term value and were close to extreme weather. Statistical analysis of long-term indicators of the air temperature regime is evidence of a steady trend towards an increase in average annual air temperature with significant fluctuations in indices in separate periods from $7.9 \pm 2.9$ to $10.0 \pm 2.5^{\circ} \mathrm{C}$ and a decrease in the amount and instability of natural moisture entry.

The influence of weather conditions on the formation of productivity of spiked cereals (winter and spring wheat, spring barley) and maize was assessed at the current agrometeorological risks in the forest steppe of Ukraine. Based on the correlation-regression analysis, mathematical models were created that reproduce the dependence of grain yields upon the complex weather conditions of the growing season, the impact of which reached $60-70 \%$. The conditions of eight years (2006-2008, 2011-2014 and 2016), when the hydrothermal index for the vegetation period was 1.13-1.76, turned out to be optimal by hydrothermal indicators to harvest maize yield at 
5.83-9.47 t/ha. However, the years of 2005, 2009-2010 and 2015 were unfavorable as they received precipitation by $120 \mathrm{~mm}$ lower than a norm or $36 \%$ of the norm. The rainfall by $37-61 \%$ lower than a norm in June-July and grain yield 3.12-6.51 t/ha were also characteristic of the years mentioned above.

Keywords: hydrothermal conditions, moisture accumulation, hydrothermal coefficient, vegetation period, productivity of crops.

\section{Introduction}

The global scientific community concludes that the Earth's climate keeps on changing. Changes that destabilize not only natural ecosystems but also economies are becoming more widespread. Many modern challenges, namely the scarcity of fresh water, energy and food, the biodiversity decline, the increase in the number and intensity of natural phenomena, the soil degradation and other problems, are largely due to the climate alteration. Scientists claim that, in recent years, climate change in Europe has gathered pace through the increasing variability in air temperature and rainfall dynamics (Pachauri and Meyer, 2014; Collins et al., 2013; Huang et al., 2016; Feng and Fu, 2013; Lin et al., 2016; Fu et al., 2016; Litvinov et al., 2019).

The issue of the smooth functioning of agriculture, which is the most important sector of the economy yet the most climate-dependent and vulnerable, is particularly important. Adaptation measures are therefore needed to mitigate the inevitable climate impacts and their economic, environmental and social costs. The rational use of agricultural land is a priority area of sustainable development policy and environmental security while maintaining the sustainability of agriculture is one of the conditions for stability of the country (Collins et al., 2013; Huang et al., 2016; Feng and Fu, 2013; Karpenko et al., 2019).

In Europe, for instance in Moldova, the country geographically close to Ukraine, scientists and farmers establish facts of climate change with an increasing frequency. In particular, air temperatures are supposed to rise by an average of $4.1-5.4^{\circ} \mathrm{C}$ by the end of this century, and maximum warming will occur in winter and during the transition period. Over time horizons of 2010-2039 and 2040-2069, the amount of precipitation is due to decrease by $9.0 \mathrm{~mm}$ and $38 \mathrm{~mm}$, respectively. While winter and spring precipitations are expected to slightly increase in quantity during warm and humid winter periods, however, summer and autumn periods will be hot and dry (Malienko and Borys, 2019). Hence, the climate change in the country over the period until 2050 will lead to a decrease in crop yields by 10-30\% (Müller et al., 2016a; Nikolayeva et al., 2012). Thus, between 1990 and 2015, there were 11 droughts registered in Moldova. It was estimated that, due to unfavorable hydrothermal conditions, the average annual income from agriculture in 2008 was by $19 \%$ lower than in the previous two years. The drought of 2012, which also had a negative impact on crop productivity in Ukraine (Schelling et al., 2003; Váňová et al., 2006; World Agricultural Production (WAP) Circular, 2020; Tack and Nalley, 2015; Lobell and Burke, 2010) led to a decrease in wheat yields by $16 \%$, maize by $30 \%$, and sunflower by $41 \%$ compared with 2009-2011. According to the studies of the International Institute for Applied Systems Analysis (IIASA), all the territory will experience a moderate decrease in wheat yields by 2025 and a significant decrease by $25 \%$ in 2050 , maize yield will wane to $25 \%$ in the central agroecological alteration zone by 2025 and for almost the entire territory of the country by 2050 (World Agricultural Production (WAP) Circular, 2020; Tack and Nalley, 2015; Malienko and Borys, 2019; Müller et al., 2016b).

The climate of Ukraine has the same trends as the climate of the entire Earth; however, the warming rate is above the global average. This is the main feature of the heterogeneity of climate change in Ukraine (Adamenko, 2017; Adamenko and Prokopenko, 2011). The climate change trend in Ukraine is not linearly growing after 1970-1980 (Fig. 1). 
Fig. 1. The temperature air $\geq 10^{\circ} \mathrm{C}$, days

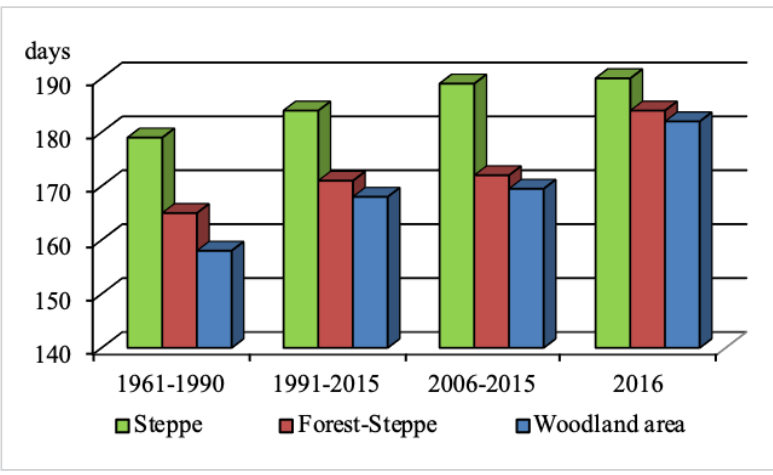

Notes: *the air temperature higher than $+10^{\circ} \mathrm{C}$ in the years from 1961 to 1990 was peculiar to 168 days; from 1991 to 2015 it was characteristic of 174 days; from 2006 to 2016 it was peculiar to 178 days

Studies have shown that over the past 20 years extreme weather phenomena tend to a moderate increase in intensity. There is a rise in summer air temperature by $1.0-2.0^{\circ} \mathrm{C}$ and an increase of absolute maxima of air temperature by $1.0-4.0^{\circ} \mathrm{C}$. The expanded number of days with very high temperatures resulted in the growth of heat resources by $200-400^{\circ} \mathrm{C}$ as well as the formation of a zone with a heat supply of more than $3400^{\circ} \mathrm{C}$ (Fig. 2), a zone of subtropical agriculture (rice, cotton, grapes) (Adamenko, 2014; Adamenko, 2017; Adamenko and Prokopenko, 2011).

During the active crop vegetation period, there is an increase in the aridity of the climate in the areas that have previously been subject to sufficient humidification. The areas of the wet agro-climatic zone (woodland area) and unstable moistening (forest steppe) are decreasing and the dry agro-climatic zone (steppe) is expanding. The continentality has decreased by $3.0-5.0^{\circ} \mathrm{C}$ over the last 30 years due to the increase of winter air temperatures and the decrease of daily flow in the summer (Fig. 3).

Over the last decades, the climate of Ukraine has modified, which can lead to a shift in the climatic seasons, changes in the duration of the growing season, a decrease in the duration of a stable snow cover and changes in the water resources of local runoff. The average annual temperature over the years 19912010 increased by $0.8^{\circ} \mathrm{C}$, over the period from 1991 to 2016 by $1.0^{\circ} \mathrm{C}$, and in 2017 by $1.8^{\circ} \mathrm{C}$ regarding the
Fig. 2. The change in the sum of active air temperatures higher than $10^{\circ} \mathrm{C}$

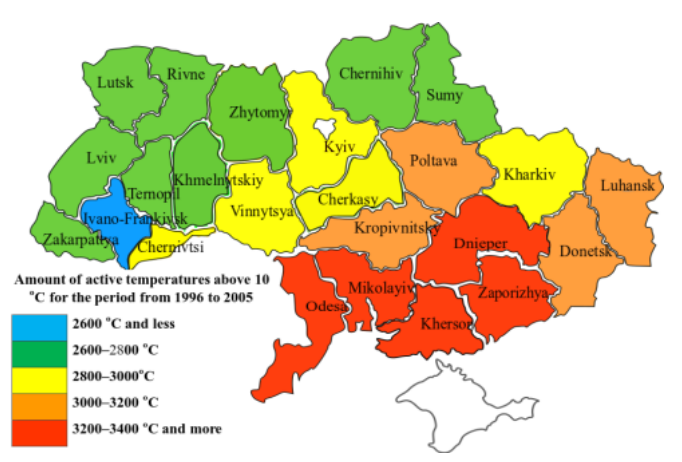

a) the sum of active air temperatures $\geq 10^{\circ} \mathrm{C}, 1996-2005$

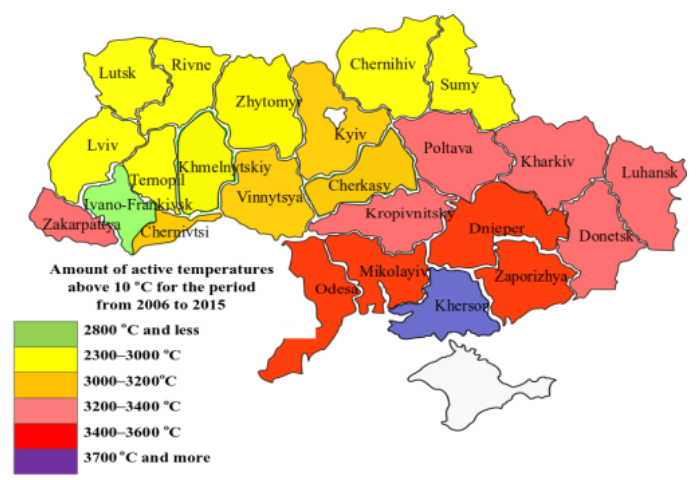

b) the sum of active air temperatures $\geq 10^{\circ} \mathrm{C}, 2006-2015$

climatic norm. The changes that occurred during the annual cycle indicate an increase in the average daily air temperature in December-January by $1.9-2.0^{\circ} \mathrm{C}$, in March by $2.3^{\circ} \mathrm{C}$, in April by $0.5^{\circ} \mathrm{C}$, in August by $1.6^{\circ} \mathrm{C}$, in September and October by $1.4-2.0^{\circ} \mathrm{C}$ (Adamenko, 2014; Bozhko et al., 2005; Ivanyi, 2015; Devitt and Polityuk, 2018).

Thus, the climate changes at both global and regional levels tend to lead to large-scale socio-economic transformations. Therefore, in this context, the problem of the smooth functioning of agriculture, the most important sector of the economy yet the most climate-dependent and vulnerable, is particularly important in meeting the human food needs. 
Fig. 3. Extension of the zone with low precipitation rates during the crop vegetation period

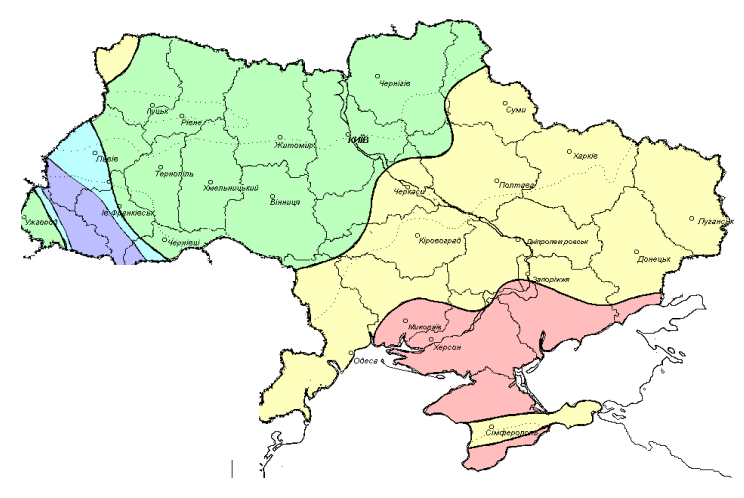

a) rainfall $(\mathrm{mm})$ in April-October, 1996-2005

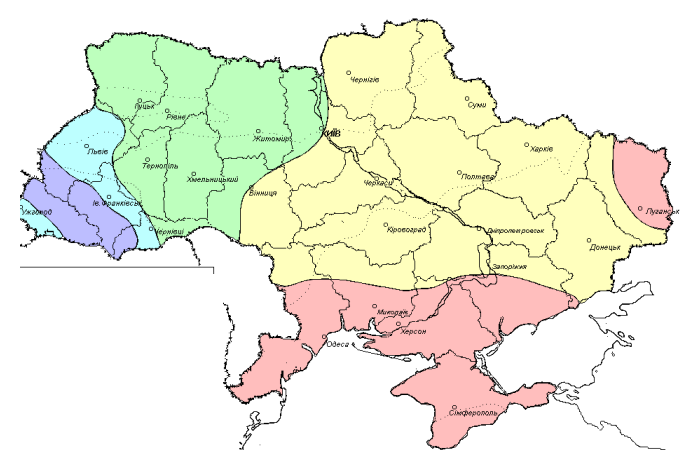

b) rainfall $(\mathrm{mm})$ in April-October,2006-2015

Scale for the map

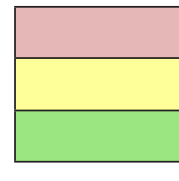

$201-300 \mathrm{~mm}$
$301-400 \mathrm{~mm}$
$401-500 \mathrm{~mm}$

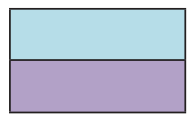

$501-600 \mathrm{~mm}$

601-700 and more

\section{Analysis of publications}

Climate change is projected to undermine food security. According to the forecasted changes, industrial production will keep on declining through the middle of the $21^{\text {st }}$ century and even further. In the case with wheat, rice and maize in tropical and temperate regions, the climate change without adaptation will adversely affect their productivity after the temperature increase by $2.0^{\circ} \mathrm{C}$, although in some places it will benefit. A global temperature rise by $4.0^{\circ} \mathrm{C}$, combined with an increasing demand for food, will pose significant risks to food security worldwide (Lipinskyi, 2002; Shevchenko et al., 2014; Adamenko, 2017). In Ukraine, about $45 \%$ of extremely fertile black soils due to the high content of organic matter and favorable structure of the topsoil can ensure deep water penetration (Driessen et al., 2000; Malienko and Borys, 2019).

However, more than $30 \%$ of the most productive lands experience a constant moisture deficit. Even in the "optimal" years, the total rainfall in the arid lands of the steppe and southern forest steppe does not exceed 400-500 mm, which is on the verge of efficient agricultural production. The situation is exacerbated in the years with precipitation of $250-350 \mathrm{~mm}$, which is much lower than the norm (Fig. 4).

During the years of severe droughts, the negative deviation of the grain yields from the average indicators of the years under study amounts to $0.05 \mathrm{t} / \mathrm{ha}$ as a whole in Ukraine and up to $0.1-0.15 \mathrm{t} / \mathrm{ha}$ in the regions of the steppe zone (Adamenko and Prokopenko, 2011; Adamenko, 2017; Kolisnyk et al., 2019). The analysis of agrometeorological observations shows that droughts, which can hit more than $50 \%$ of the territory of Ukraine, occur on average 1 time every 10-12 years. Over the period of 1981-2013, atmospheric and soil droughts of various intensity (spring-summer, summer, autumn) were observed in Ukraine almost every year, and only in 1993 and 1997, they were not fixed (Adamenko, 2014; Pachauri and Meyer, 2014). 
Fig. 4. Crop yield dependence on hydrothermal conditions, centner/per hectare

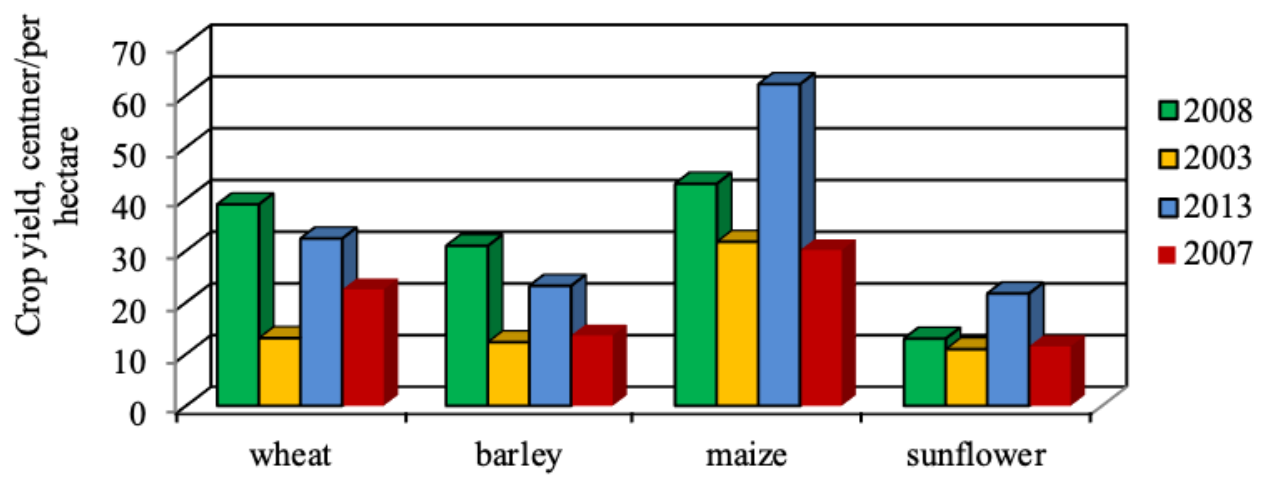

The purpose of the research was to evaluate the impact of modern climate change on the productivity of grain crops (winter and spring wheat, spring barley and maize) in the forest steppe of Ukraine.

\section{Methods}

The typicality of weather conditions and the impact of the method of basic tillage on crop productivity were objects of the long-term research stationary experiments of the National Scientific Center «Institute of Agriculture of NAAS». The typical nature of weather conditions was determined by the amount of rainfall and the average daily air temperature for a particular month of the growing season. The typicality of hydrothermal conditions was expressed through Ci according to Manko (2007) and Asfaw (2016), and the deviation materiality coefficient of hydrothermal conditions from the norm was defined according to the recommendations. The mathematical analysis of the experimental data was performed based on the correlation coefficient $r$, and determination $D$. This analysis shows to what extent the variability $(y)$, as a productive sign, is explained by the factor sign $(\mathrm{x})$ HTC (World Bank, CIAT, 2016).

The presented results of the correlation-regression analysis made it possible to assess the influence of each of the factors and determine the level of significance of the studied factors. Calculations based on correlation models increase the accuracy of the analysis and often reveal the shortcomings of the preliminary analysis. Moreover, this method also provides an opportunity to solve problems that cannot be solved by other methods of statistical analysis, such as, for instance, the division of the influence of many factors that are interrelated and interdependent.

\section{Results and Discussion}

Generalization of the long-term indicators of air thermal regime indicates a steady tendency towards the increase in the average annual temperature of the air over the last 13 years. The observation period from 2004 to 2009 was characterized by significant fluctuations in the studied indicators. The largest deviations from the mean value occurred in 2006 and 2007, which were $1.1^{\circ} \mathrm{C}$ and $0.7^{\circ} \mathrm{C}$, respectively. The results of the statistical analysis according to which the average annual air temperature varied from $7.9 \pm 2.9$ to $10.0 \pm 2.5^{\circ} \mathrm{C}$ are also evidence of a steady increase in the air temperature. The air temperature varied from $10.9^{\circ} \mathrm{C}$ to $-4.0^{\circ} \mathrm{C}$ and the maximum was from $20.0^{\circ} \mathrm{C}$ to $24.4^{\circ} \mathrm{C}$. Along with this, the results of our studies revealed a significant amplitude of the air temperature fluctuations both within individual years ( $V=88.2-130.1 \%)$ and individual months. The highest variability of the average monthly temperature was in the winter months and March, which is confirmed by the coefficients of variation, which respectively amounted to $192.05 \%$ in December, $68.7 \%$ in January, 
Table 1. Statistical indexes of hydrothermal conditions, 2004-2016

\begin{tabular}{|c|c|c|c|c|c|}
\hline \multirow[b]{2}{*}{ Month } & \multicolumn{5}{|c|}{ Statistical indexes } \\
\hline & $\bar{X} \pm S_{\bar{x}}$ & Min, ${ }^{\circ} \mathrm{C}$ & Max, ${ }^{\circ} \mathrm{C}$ & Coefficient of variation (V), \% & Standard deviation (S) \\
\hline \multicolumn{6}{|c|}{ temperature, ${ }^{\circ} \mathrm{C}$} \\
\hline January & $-4.2 \pm 0.8$ & -9 & 1.5 & 68.7 & 2.91 \\
\hline February & $-3.5 \pm 1.0$ & -10.9 & 1.5 & 98.2 & 3.46 \\
\hline March & $2.0 \pm 0.8$ & -2.4 & 5.9 & 139.9 & 2.80 \\
\hline April & $10.0 \pm 0.3$ & 8.5 & 12.4 & 11.8 & 1.18 \\
\hline May & $16.3 \pm 0.5$ & 13.2 & 19.2 & 11.3 & 1.84 \\
\hline June & $19.6 \pm 0.4$ & 17.2 & 21.9 & 7.9 & 1.55 \\
\hline July & $21.5 \pm 0.3$ & 20.0 & 24.4 & 5.8 & 1.24 \\
\hline August & $20.6 \pm 0.4$ & 18.7 & 24.3 & 6.9 & 1.42 \\
\hline September & $14.9 \pm 0.4$ & 12.4 & 17.7 & 8.8 & 1.31 \\
\hline October & $8.2 \pm 0.4$ & 5.9 & 10.2 & 18.4 & 1.51 \\
\hline November & $3.3 \pm 0.6$ & 0.5 & 7.7 & 64.5 & 2.15 \\
\hline December & $-1.1 \pm 0.6$ & -4.8 & 2.1 & 192.0 & 2.17 \\
\hline \multicolumn{6}{|c|}{ precipitation, mm } \\
\hline January & $38.2 \pm 5.2$ & 3.0 & 67.0 & 49.4 & 18.9 \\
\hline February & $38.8 \pm 5.4$ & 7.7 & 74.0 & 50.5 & 19.6 \\
\hline March & $37.8 \pm 6.3$ & 10.5 & 84.0 & 60.3 & 22.8 \\
\hline April & $31.2 \pm 6.7$ & 1.1 & 83.0 & 77.2 & 24.1 \\
\hline May & $60.6 \pm 10.2$ & 18.0 & 134.0 & 60.8 & 36.8 \\
\hline June & $61.4 \pm 8.4$ & 17.0 & 112.0 & 49.1 & 30.1 \\
\hline July & $66.9 \pm 17.0$ & 21.0 & 252.0 & 91.4 & 61.1 \\
\hline August & $54.4 \pm 13.3$ & 2.0 & 191.0 & 87.9 & 47.8 \\
\hline September & $49.9 \pm 11.5$ & 3.0 & 144.0 & 82.9 & 41.4 \\
\hline October & $37.8 \pm 7.2$ & 10.0 & 98.5 & 68.7 & 25.9 \\
\hline November & $35.2 \pm 5.3$ & 1.4 & 66.0 & 53.9 & 19.0 \\
\hline December & $41.3 \pm 7.2$ & 6.0 & 82.0 & 62.6 & 25.8 \\
\hline
\end{tabular}

98.2\% in February and $139.9 \%$ in March. The slightest fluctuations in the air temperature were observed in the summer months $(\mathrm{V}=5.8-7.9 \%)$ (Table 1$)$.

The largest deviations from the norm occurred in 2006 and 2007, which were $1.1^{\circ} \mathrm{C}$ and $0.7^{\circ} \mathrm{C}$, respectively. The results of the statistical analysis with a variation from $7.9 \pm 2.9$ to $10.0 \pm 2.5^{\circ} \mathrm{C}$ (Fig. 5a) prove a steady increase in the air temperature. Further decreasing of annual rainfall can be predicted by the trend line (Fig. $5 b$ ).

\section{Analysis of the dependence of productivity of cereals on the meteorological conditions of cultivation}

The established correlation and determination coefficients make it possible to characterize the dependence of wheat and barley yield on the weather conditions of the growing season. The greatest effect of the air temperature was during June for wheat $D=56.6 \%$ and for barley $D=47.2 \%$, and that of rainfall was 
Fig. 5. Annual change in average daily air temperature (a) and precipitation (b)
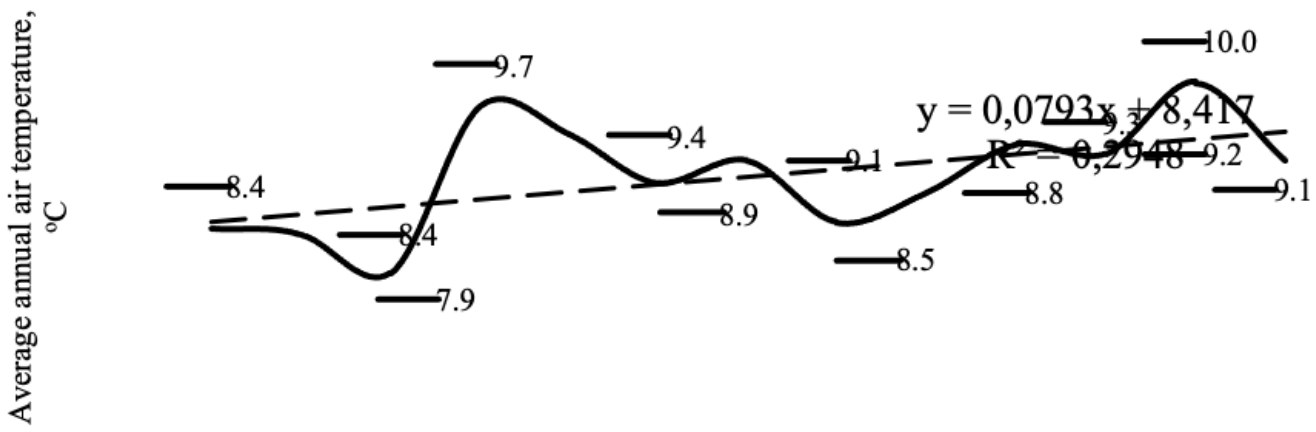

_ temperature, ${ }^{\circ} \mathrm{C} \ldots \ldots$ trend line

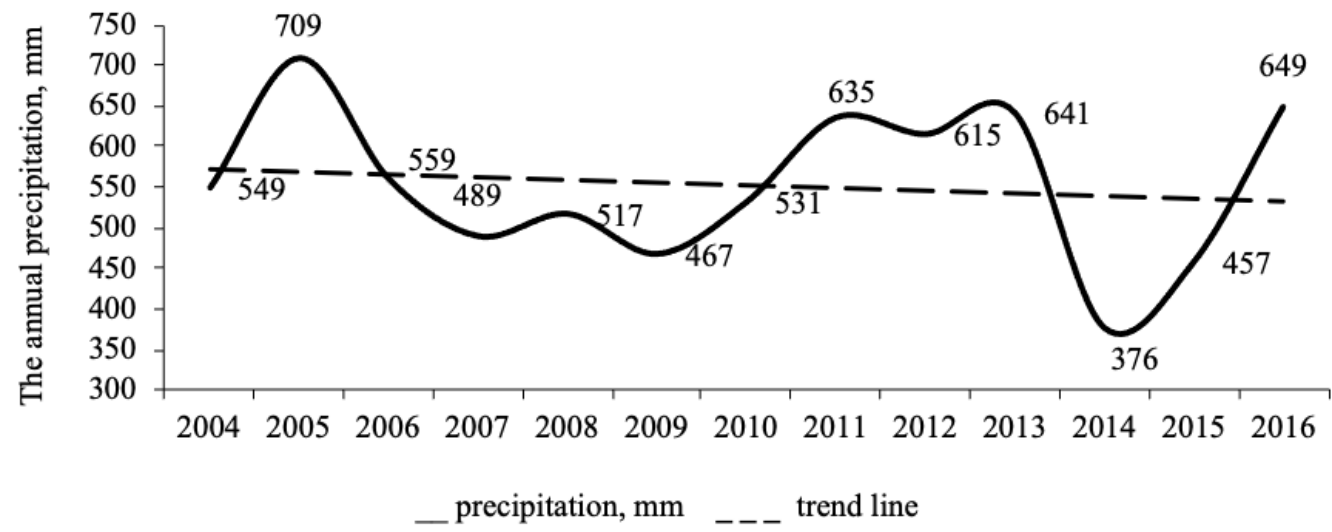

Table 2. Correlation of yields and hydrothermal conditions, 2004-2016

\begin{tabular}{|l|l|l|l|l|}
\hline \multirow{3}{*}{ Month } & \multicolumn{2}{|c|}{ Temperature, ${ }^{\circ} \mathrm{C}$} & \multicolumn{2}{|c|}{ Precipitation, mm } \\
\cline { 2 - 4 } & $\begin{array}{l}\text { Coefficient of } \\
\text { correlation, } r\end{array}$ & $\begin{array}{l}\text { Determination of } \\
\text { correlation, } D, \%\end{array}$ & $\begin{array}{l}\text { Coefficient of } \\
\text { correlation, } r\end{array}$ & $\begin{array}{l}\text { Determination of } \\
\text { correlation, } \mathrm{D}, \%\end{array}$ \\
\hline
\end{tabular}

\begin{tabular}{l|c|c|c|c}
\hline \multicolumn{5}{|c}{ Winter wheat } \\
\hline April & 0.139 & 1.9 & 0.145 & 2.1 \\
\hline May & -0.485 & 23.6 & 0.716 & 51.2 \\
\hline June & -0.752 & 56.6 & -0.124 & 1.5 \\
\hline July & -0.334 & 11.2 & -0.326 & 10.6
\end{tabular}

\begin{tabular}{l|c|c|c|c}
\hline \multicolumn{5}{|c}{ Spring barley } \\
\hline April & 0.067 & 0.5 & 0.057 & 0.3 \\
\hline May & -0.313 & 9.8 & 0.675 & 45.6 \\
\hline June & -0.687 & 47.2 & -0.043 & 0.2 \\
\hline July & -0.203 & 4.1 & -0.270 & 7.3 \\
\hline
\end{tabular}


during May $D=51.2 \%$ and $D=45.6 \%$, respectively. At the same time, the relationship between the crop capacity and the amount of precipitation was direct; however, it was reversed with the air temperature (Table 2).

Having examined in detail the changes in the distribution of rainfall that occurred during the growing season of maize in the studied years, it should be noted that the first half of the vegetation period (May-June) was chiefly characterized by the following level of rainfall: 5 years demonstrated an optimal level of 49.0 $\mathrm{mm}, 4$ of them had an insignificantly lowered level of $37 \mathrm{~mm}$, and during 3 years the monthly amount of precipitation averaged $128 \mathrm{~mm}$, which was by $78 \mathrm{~mm}$ above normal or by $146 \%$ higher than the norm, and in the second half of the growing season, on the contrary, these indicators decreased (Fig. 6a).

The temperature regime and changes that occurred during the analyzed vegetation period of maize indicate the increase in air temperature by $0.3-2.7^{\circ} \mathrm{C}$ in July, by $2.6-$ $4.1^{\circ} \mathrm{C}$ in August and by $1.7-3.1^{\circ} \mathrm{C}$ in September (Fig. 6b). In contrast to the rainfall, the air temperature is a less critical indicator in the formation of corn productivity. An increase in the sum of active air temperatures during the growing season in the Right Bank Forest Steppe zone allows expanding the range of hybrids from midseason to mid-late hybrids, which are more productive.

Fig. 6a. Dynamics of rainfall $(\mathrm{mm})$ during the vegetation period of maize in the forest steppe

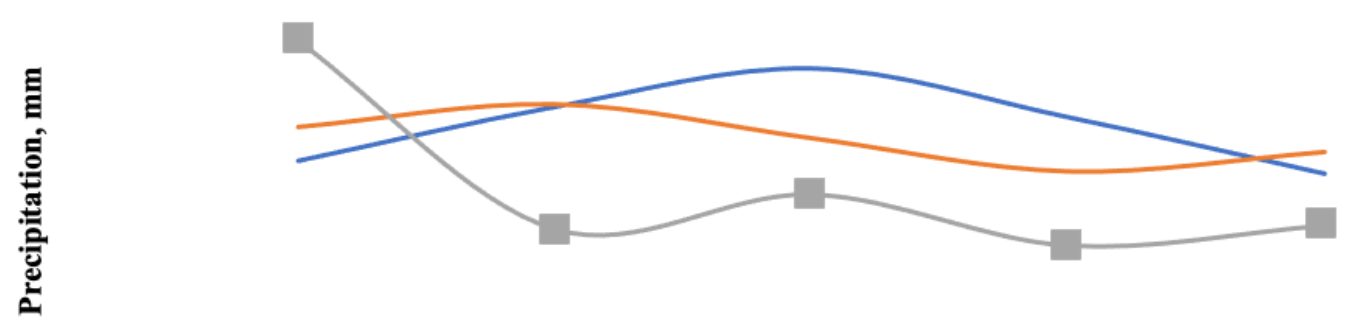

\footnotetext{
— the rainfall average for the last 50 years (norm for agroclimatic zone)

- the monthly precipitation for 2005-2016

- - the monthly precipitation for 2014-2016
}

Fig. $\mathbf{6 b}$. Temperature $\left({ }^{\circ} \mathrm{C}\right)$ during the vegetation period of maize in the forest steppe

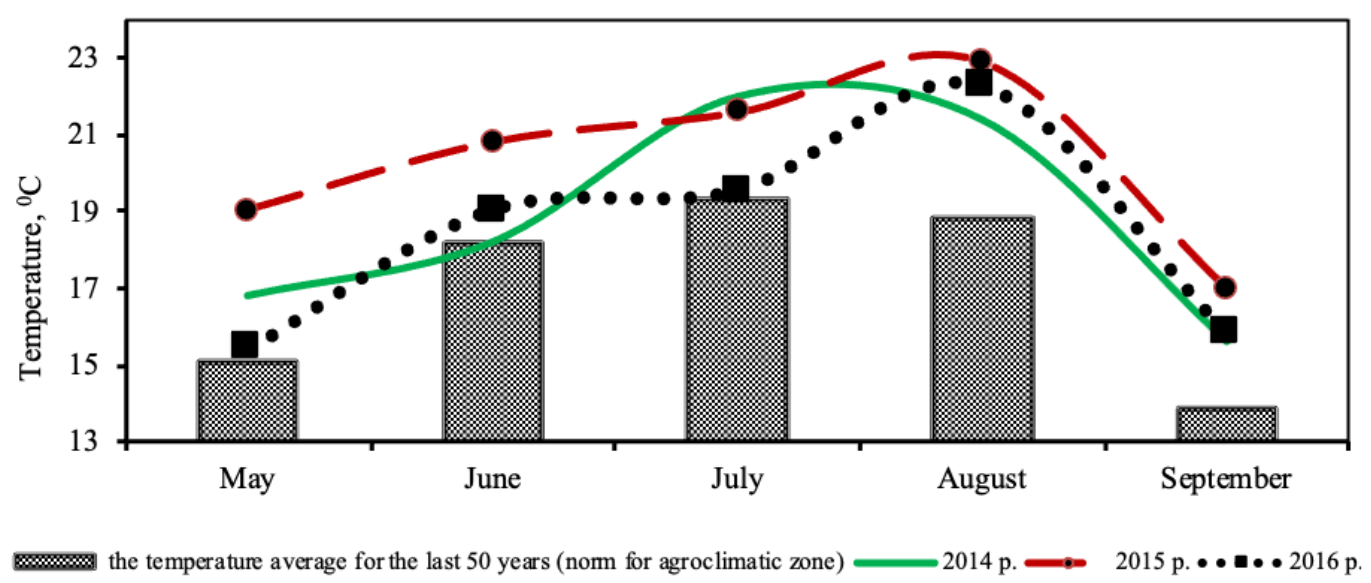


The hydrothermal conditions (HTC 0.30-1.13) were unfavorable in 2005, 2009-2010 and 2015 with the rainfall of $120-288 \mathrm{~mm}$, which was by $120 \mathrm{~mm}$ below the long-term amount and made $36 \%$. The rainfall lower by $37-61 \%$ in June-July was characteristic of these years, but for all that grain yields ranged 3.12$6.51 \mathrm{t} / \mathrm{ha}$. In the years with an optimal hydrothermal coefficient (HTC 1.13-1.76), grain yield was in the range from 6.35 to $9.47 \mathrm{t} / \mathrm{ha}$. Under favorable weather conditions in 2006 and 2014, the highest levels of yield were obtained by using chisel tillage $(9.47 \mathrm{t} / \mathrm{ha})$, while the grain harvest was by $27 \%$ lower after disking at the depth of $10-12 \mathrm{~cm}$. The yield reduction following disking compared with the control and chisel loosening of the soil in the years with optimal HTC made 0.75 $\mathrm{t} / \mathrm{ha}$, and in dry years it was $1.35 \mathrm{t} /$ ha (Table 3 ).

The unfavorable hydrothermal conditions that have been observed in recent years and reflected in the rise of average daily air temperature and precipitation deficits have a negative impact on the formation of corn productivity, as evidenced by the pair correlation coefficient. During May-June with different ways of basic soil cultivation, the correlation coefficients indicate a slight inverse dependence of $r=-0.245 \ldots$ -0.407 , while the average level of $r=-0.439 \ldots-0.524$ was observed in July (Table 4).

On the basis of mathematical and statistical calculations regarding the typicality of hydrothermal conditions in terms of precipitation and air temperature, it was found that the conditions in the context of the $12^{\text {th }}$ period were significantly different from the long-term conditions over the last 50 years. The increase in the sum of active air temperatures $\left(2300-3400^{\circ} \mathrm{C}\right)$ during the maize growing season in the Right Bank Forest Steppe zone, which have been particularly different over the last five years, makes it possible to expand the range of more productive hybrids for sowing with a higher number of FAO.

Table 3. Influence of the method of basic tillage and hydrothermal conditions on maize yield, 2005-2016, t/ha

\begin{tabular}{|c|c|c|c|c|c|c|}
\hline \multirow[b]{2}{*}{$\begin{array}{l}\text { Years grouping by } \\
\text { weather conditions }\end{array}$} & \multirow[b]{2}{*}{ Years } & \multirow[b]{2}{*}{ HTC } & \multicolumn{4}{|c|}{ Maize yield, t/ha } \\
\hline & & & $\begin{array}{l}\text { Ploughing at the } \\
\text { depth } \\
\text { of } 28-30 \mathrm{~cm} \\
\text { (control) }\end{array}$ & $\begin{array}{l}\text { Flat-cut tilling at the } \\
\text { depth } \\
\text { of } 28-30 \mathrm{~cm}\end{array}$ & $\begin{array}{l}\text { Chisel ploughing at } \\
\text { the depth } \\
\text { of } 43-45 \mathrm{~cm}\end{array}$ & $\begin{array}{l}\text { Disking at the } \\
\text { depth } \\
\text { of } 10-12 \mathrm{~cm}\end{array}$ \\
\hline \multirow{8}{*}{ Optimal by HTC } & 2006 & 1.49 & 8.44 & 8.30 & 9.47 & 7.33 \\
\hline & 2007 & 1.29 & 7.76 & 6.68 & 6.68 & 6.35 \\
\hline & 2008 & 1.76 & 7.02 & 7.14 & 6.86 & 6.88 \\
\hline & 2011 & 1.30 & 7.53 & 7.25 & 7.34 & 7.32 \\
\hline & 2012 & 1.23 & 6.10 & 6.28 & 6.21 & 6.35 \\
\hline & 2013 & 1.25 & 6.19 & 5.90 & 6.16 & 5.83 \\
\hline & 2014 & 1.13 & 8.26 & 7.96 & 8.24 & 8.02 \\
\hline & 2016 & 0.66 & 8.53 & 8.18 & 8.71 & 7.73 \\
\hline Average & & & 7.48 & 7.21 & 7.46 & 6.98 \\
\hline \multirow{4}{*}{ Unfavorable by HTC } & 2005 & 1.03 & 3.92 & 3.88 & 3.76 & 3.90 \\
\hline & 2009 & 0.92 & 5.17 & 5.14 & 6.51 & 5.58 \\
\hline & 2010 & 1.13 & 3.68 & 4.36 & 4.32 & 3.12 \\
\hline & 2015 & 0.39 & 6.08 & 5.62 & 5.90 & 5.24 \\
\hline Average & & & 4.71 & 4.75 & 5.12 & 4.46 \\
\hline
\end{tabular}

Note. The yield of maize for 2005-2012 is given according to the reports of the Department of Soil and Weed Control NSC «Institute of Agriculture of NAAS». 
Table 4. Influence of precipitation and temperature on maize yield by different methods of soil tillage

\begin{tabular}{|c|c|c|c|c|c|}
\hline \multirow[b]{2}{*}{ Factor } & \multirow[b]{2}{*}{ Month } & \multicolumn{4}{|c|}{ Different ways of basic soil cultivation } \\
\hline & & $\begin{array}{l}\text { Ploughing at the } \\
\text { depth } \\
\text { of } 28-30 \mathrm{~cm} \\
\text { (control) }\end{array}$ & $\begin{array}{c}\text { Flat-cut tilling at the } \\
\text { depth } \\
\text { of } 28-30 \mathrm{~cm}\end{array}$ & $\begin{array}{c}\text { Chisel ploughing at the } \\
\text { depth } \\
\text { of } 43-45 \mathrm{~cm}\end{array}$ & $\begin{array}{c}\text { Disking at the } \\
\text { depth } \\
\text { of } 10-12 \mathrm{~cm}\end{array}$ \\
\hline \multirow{5}{*}{ Precipitation, $\mathrm{mm}$} & May & 0.496 & 0.551 & 0.576 & 0.467 \\
\hline & June & 0.203 & 0.234 & 0.183 & 0.300 \\
\hline & July & 0.173 & 0.173 & 0.092 & 0.070 \\
\hline & August & -0.026 & -0.081 & -0.185 & -0.033 \\
\hline & September & -0.093 & -0.075 & -0.109 & -0.118 \\
\hline \multirow{5}{*}{ Temperature, ${ }^{\circ} \mathrm{C}$} & May & -0.245 & -0.370 & -0.452 & -0.347 \\
\hline & June & -0.317 & -0.389 & -0.315 & -0.407 \\
\hline & July & -0.524 & -0.439 & -0.450 & -0.522 \\
\hline & August & -0.346 & -0.323 & -0.432 & -0.519 \\
\hline & September & -0.250 & -0.276 & -0.137 & -0.177 \\
\hline
\end{tabular}

\section{Conclusions}

It has been ascertained that the specifics of the dynamics of precipitation during the vegetation period of early spring cereals (wheat, barley) as well as late spring crops (corn) indicate certain changes in time with a tendency to increase their volume in May-June and a significant decrease in July-August. Drastic changes in the amount of precipitation particularly in 2011-2015 are evidence of their atypy, and the changes in air temperature indicate climate changes in the Right Bank Forest Steppe zone towards aridity.

By the average monthly air temperature more than a half of the years studied (2004-2016) and by rainfall nearly a third part of the researched period differed significantly from the average long-term value and were close to extreme weather. The statistical analysis of longterm indicators of the air temperature regime shows a steady trend towards an increase in the average annual air temperature with significant fluctuations in indices in separate periods from $7.9 \pm 2.9$ to $10.0 \pm 2.5^{\circ} \mathrm{C}$. The actual average annual figures of sums of precipitation indicate a decrease in the amount and instability of the natural moisture receipt.

The productivity of spring wheat and barley and winter wheat depended on the complex of weather conditions in May and June, with the effect on the yield of the crops reaching $60-70 \%$.

The conditions of eight years (2006-2008, 2011-2014 and 2016), when the hydrothermal index for the vegetation period was 1.13-1.76, turned out to be optimal by the hydrothermal indicators to harvest maize yield at 5.83-9.47 t/ha. However, the years of 2005, 2009-2010 and 2015 were unfavorable as they received precipitation by $120 \mathrm{~mm}$ lower than a norm or $36 \%$ of the norm (average long-term value for the last 50 years). The rainfall by $37-61 \%$ lower than a norm in June-July and grain yield $3.12-6.51 \mathrm{t} / \mathrm{h}$ a is a salient feature of these years. 


\section{References}

Adamenko T. (2017) Agricultural drought monitoring in Ukraine: Presentation during EvIDENz Workshop. Ukrainian Hydrometeorological Centre.

Adamenko T. and Prokopenko A. (2011) Monitoring Droughts and Impacts on Crop Yields in Ukraine from Weather and Satellite Data. In Use of Satellite and In-Situ Data to Improve Sustainability, Felix Kogan, and others, eds. Available at:https://link.springer. com/content/pdf/bfm\%3A978-90-481-9618-0\%2F1.pdf

Adamenko T.I. (2014) Agroclimatic zoning of the territory of Ukraine on the basis of climate change. Kyiv, 20.

Asfaw S. (2016) Gender integration into climate-smart agriculture. Rome: Maggio, Food and Agriculture Organization of the UN, 20. http://www.fao.org/3/a-i5299e.pdf

Bozhko L.Yu., Barsukov O.A. and Adamenko T.I. (2005) Agrometeorological conditions of the corn crop in Ukraine. Mizhvid. Science. Coll. Ukraine meteorology, climatology and hydrology. Odessa, 49, 285-294.https://graintrade.com.ua/en/novosti/ agrometeorologichni-umovi-v-ukraini-ne-spriyayut-rozvitku-zernovih-kultur.html

Collins M. et al. (2013) Climate Change. The Physical Science BasisIPCC, Cambridge Univ. Press, Cambridge, UK.

Devitt P. and Polityuk P. (2018) Russia and Ukraine face lower grain crops in 2018 due to dry weather. https://www.agriculture.com/markets/newswire/russia-and-ukraine-face-lowergrain-crops-in-2018-due-to-dry-weather

Driessen P., Spaargaren O. and Nachtergaele F. (2000) Lecture Notes on the Major Soils of the World. Rome: FAO.

Feng S. and Fu Q. (2013) Expansion of global drylands under a warming climate. Atmos. Chem. Phys., 13, 10081-10094. https://doi.org/10.5194/acp-13-10081-2013

Fu Q., Lin L., Huang J., Feng S. and Gettelman A. (2016) Changes in terrestrial aridity for the period 850-2080 from the Community Earth System Model. J. Geophys. Res. Atmos. 121, 2857-2873. https://doi.org/10.1002/2015JD024075

Huang J.Yu, Guan H.X., Wang G. and Guo R. (2016) Accelerated dryland expansion under climate change. Nat. Clim. Change, 6, 166-171. https://doi.org/10.1038/nclimate2837

IvanyiZs, (2015) Increasing resistance to change agricultural climate sector of southern Ukraine. Regional environmental centre. Szentendre, Hungary, 76.

Karpenko O.Yu., RozhkoV.M., Butenko A.O., Masykl.M., MalynkaL.V., Didur I.M., Vereshchahin I.V., Chyrva A.S. and Berdin S.I. (2019) Post-harvest side rates impact on the weed littering of maize, 2019, 9(3), 300-303. https://doi.org/10.15421/2019_94
Kolisnyk O.M., Butenko A.O., Malynka L.V., Masik I.M., Onychko V.I., Onychko T.O., Kriuchko L.V. and Kobzhev O.M. (2019) Adaptive properties of maize forms for improvement in the ecological status of fields. Ukrainian Journal of Ecology, 2019, 9(2), 3337.http://socrates.vsau.org/repository/getfile.php/20565.pdf

Lin L., Gettelman A., Fu Q. and Xu Y. (2016) Simulated differences in 21 st century aridity due to different scenarios of greenhouse gases and aerosols. Climatic Change. https://doi.org/10.1007/ s10584-016-1615-3

Lipinskyi V.M. (2002) Global climate change and its response to the dynamics of Ukraine's climate. Investytsii ta zminaklimatu: mozhlyvosti dlia Ukrainy: Mizhnar. konf. Kyiv, 10-11 july.

Litvinov D.V., ButenkoA.O., Onychko V.I., OnychkoT.O.,MalynkaL.V., Masykl.M.,Bondarieva L.M. and Ihnatieva O.L. (2019) Parameters of biological circulation of phytomass and nutritional elements in crop rotations. Ukrainian Journal of Ecology, 9(3), 92-98. https://doi.org/10.15421/2019_714

Lobell D.B. and Burke M.B. (2010) On the use of statistical models to predict crop yield responses to climate change. Agricultural and Forest Meteorology, 150(11), 1443-1452. https://doi. org/10.1016/j.agrformet.2010.07.008

Malienko A.M.and Borys N.Ye. (2019) Typical hydrothermal conditions of the Right-bank Forest-step zone and their influence on corn productivity. AGROBIOLOGY №1, 55-64. https://doi. org/10.33245/2310-9270-2019-146-1-55-64

Manko lu.P. (2007) Methods of assessing the adequacy of phenomena and technologies in agriculture. Naukovi pratsi Instytutu bioenerhetychnykh kultur i tsukrovykh buriakiv. Vol. 9, 26-31.

Müller D., Jungandreas A. and Koch F.J. (2016) Impact of climate change on wheat production in Ukraine. Florian Schierhorn. Agrarian Policy Report. Kyiv: The Institute for Economic Research and Policy Consulting, German-Ukrainian Policy Dialogue in Agriculture. http://apd-ukraine.de/images/APD_APR _05-2016_impact_on_wheat_ukr_fin.pdf

Müller D., Jungandreas A., Koch, F. and Schierhorn F. (2016) Impact of Climate Change on Wheat Production in Ukraine. Kyiv, May.

Nikolayeva L., Denisov N., and Novikov V. (2012) «Climate change in Eastern Europe: Belarus, Moldova, Ukraine» in Climate change in Eastern Europe: Belarus, Moldova, Ukraine, 60. Environment and Security Initiative (ENVSEC), Zoi Environment Network (ZOI).

Pachauri R.K. and Meyer L.A. (2014) Climate Change. Synthesis Report. Contribution of Working Groups I, II and III to the Fifth Assessment Report of the Intergovernmental Panel on Climate Change. IPCC, Geneva, Switzerland. 
Schelling K., Born K. and Weissteiner C. (2003) Relationships between yield and quality parameters of malting barley and phonological and metrological data. J. Aron. And Crop Sci. 189, № 2, 113-122. https://doi.org/10.1046/j.1439-037X.2003.00011.x Shevchenko O., Vlasiuk O., Stavchuk I. and Vakoliuk M. (2014) Climate change vulnerability assessment: Ukraine. Klimatychnyi forum skhidnoho partnerstva (KFSP) ta Robocha hrupa hromadskykh orhanizatsii zi zminy klimatu (RH NUO ZK), 74.

Tack J., Barkley A., and Nalley L.L. (2015) Effect of warming temperatures on US wheat yields. Proceedings of the $\mathrm{Na}$ - tional Academy of Sciences, 112(22), 6931-6936. https://doi. org/10.1073/pnas.1415181112

Váňová M., Palík S., Hajšlová J. and Burešová I. (2006) Grain quality and yield spring barley in fields trials under variable growing conditions. PLANT SOIL ENVIRON., 52, 211-219. https://doi.org/10.17221/3432-PSE

World Agricultural Production (WAP) Circular. (2020) Crop Explorer - Commodity Intelligence Reports - Ukraine, Moldova and Belarus. https://ipad.fas.usda.gov

World Bank, CIAT. 2016. Climate-smart agriculture in Moldova, 20.https://cgspace.cgiar.org/handle/10568/76504 